PERM JOURNAL OF PETROLEUM AND MINING ENGINEERING

ВЕСТНИК ПНИПУ. ГЕОЛОГИЯ. НЕФТЕГАЗОВОЕ И ГОРНОЕ ДЕ ЛО

ISSN 2224-9923

Volume / Tом 20 №2 2020

http://vestnik.pstu.ru/geo/

UDC 622.276.432

Article / Статья

(C) PNRPU / ПНИПУ, 2020

\title{
ANALYSIS OF GLOBAL PRACTICES OF FORMATION WATER INTAKE PROFILE STABILIZATIONS BASED ON CROSS-LINKED POLYMER GELS
}

\author{
Iuliia A. Ketova, Sergei V. Galkin, Aleksandr S. Votinov', Wanli Kang², Hongbin Yang ${ }^{2}$ \\ Perm National Research Polytechnic University (29 Komsomolsky av., Perm, 614990, Russian Federation) \\ ${ }^{1}$ PermNIPIneft branch of LUKOIL-Engineering LLC in Perm (29 Sovetskoy armii st., Perm, 614000, Russian Federation) \\ ${ }^{2}$ China University of Petroleum (East China) (66 West Changjiang Road, Huangdao District, Qindao, China, 266580)
}

\section{АНАЛИЗ МИРОВОГО ОПЫТА ПРИМЕНЕНИЯ ТЕХНОЛОГИЙ ВЫРАВНИВАНИЯ ПРОФИЛЕЙ ПРИЕМИСТОСТИ НА ОСНОВЕ СШИТЫХ ПОЛИМЕРНЫХ ГЕЛЕЙ}

\section{Ю.А. Кетова, С.В. Галкин, А.С. Вотинов ${ }^{1}$, В. Канг², Х. Янг ${ }^{2}$}

Пермский национальный исследовательский политехнический университет (614990, г. Пермь, Комсомольский пр., 29)

${ }^{1}$ Филиал ООО «ЛУКОЙЛ-Инжиниринг» «ПермНИПИнефть» в г. Перми (614000, г. Пермь, ул. Советской Армии, 29)

${ }^{2}$ Китайский нефтяной университет (Восточный университет) (266580, Янцзы Вест Роуд, 66, Циндао, Шаньдун, Китай)

Received / Получена: 12.02.2020. Accepted / Принята: 15.04.2020. Published / Опубликована: 15.06.2020

Key words:

polymer water flooding,

polyacrylamide, formation profile,

permeability, colloidal dispersion

gels, microgels, macrogels,

polymer gel particles, enhanced oil recovery.
Ключевые слова:

олимерное заводнение, полиакриламид, профиль пласта, проницаемость

коллоидные дисперсные гели, микрогели, макрогели, частиць полимерного геля, повышение нефтеотдачи.

\begin{abstract}
Due to a growing number of wells being in late stages of operation, there is an increasing demand for introduction of new integrated solutions reducing wellbore fluid watercut. Eventually, watercut reduction enables a prolonged operation of encroached wells and improves recovery of residual oil reserves. Polyacrylamide is the most available and industrially applicable reagent stabilizing formation water intake profiles. Based on the review of international and native experience, the study analyses the effectiveness of a variety of methods using polyacrylamide to reduce the wellbore fluid watercut. The paper discusses such injection technologies as conventional polymer water flooding, in situ gels, colloidal dispersion gels, and precrosslinked gels.

Cross-linked polymer gels are three-dimensional structures where polymer chains are cross-linked by either ionic or covalent polar bonds. Depending on particle sizes, they are divided into macrogels $(100 \mu \mathrm{m}$ to several $\mathrm{cm})$ and microgels $(0.1$ to $30 \mu \mathrm{m})$. Compared to in situ compounds, the use of macro- and microgels substantially reduces the risk of polymer chain destruction by mechanical, chemical or thermal factors.

Based on the analysis, recommendations were developed for application of various polymer injection methods taking into account the geological and technological conditions of the production site development. It is recommended to use macrogels to reduce the wellbore fluid watercut in fields with the reservoir permeability above $500 \mathrm{mD}$; while it is advisable to use microgels with the reservoir permeability from 100 to $500 \mathrm{mD}$; and colloidal dispersion gels can be used with the reservoir permeability from 10 to 100 $\mathrm{mD}$. In order to improve the development effectiveness, advanced technologies need to be adapted in due time to the geological and process conditions. Also pilot production operations need to be conducted in the native fields.
\end{abstract}

В связи с расширением фонда скважин, находящихся на поздней стадии эксплуатащии, увеличивается потребность во введении в производство новых комплексных технологий снижения обводненности продукции скважин. В конечном итоге снижение обводненности дает возможность длительное время эксплуатировать обводнившийся фонд, повышая выработку остаточных запасов нефти. Наиболее доступным и применимым на производстве реагентом для решения задач выравнивания профиля приемистости пласта является полиакриламид. На основе обобщения международного и отечественного опыта проведен анализ эффективности применения различных модификаций методов с использованием полиакриламида для снижения обводненности продукции скважин. Рассмотрены такие технологии закачки, как традиционное полимерное заводнение; гели типа in situ; коллоидные дисперсные гели; предварительно сшитые гели. Сшитые полимерные гели представляют собой трехмерные структуры, в которых полимерные цепи сшиты либо ионными, либо ковалентными полярными связями. В зависимости от размера частиц они подразделяются на макрогели (от 100 мкм до нескольких см) и микрогели (от 0,1 до 30 мкм). Применение макро- и микрогелей, в сравнении с составами in situ, в значительной степени снижает риски деструкции полимерных цепей от механических, химических и термических факторов. В результате анализа сформированы рекомендации по использованию различных модификаций закачки полимеров с учетом геолого-технологических условий разработки эксплуатационных объектов. Для снижения обводненности продукции скважин на месторождениях в условиях коллекторов с проницаемостью более 500 мД рекомендовано применение макрогелей; от 100 до 500 мД - микрогелей; от 10 до 100 мД - коллоидных дисперсных гелей. Для повышения эффективности разработки необходима своевременная адаптация перспективных технологий к геолого-технологическим условиям, проведение опытно-промышленных работ на отечественных месторождениях.

Iuliia A. Ketova (Scopus ID 57215592096) - Junior Researcher, Department of Oil and Gas Technologies (tel: +007 952 322 14 13, e-mail: ketova.pstu@gmail.com). Sergei V. Galkin (Scopus ID 36711675500) - Doctor of Geological and Mineralogical Sciences, Professor (tel: +007 342 219 81 18, e-mail: gnfd@pstu.ru). The contact person for correspondence.

Aleksandr S. Votinov - Engineer (tel.: +007922 36608 36, e-mail: aleksandr.votinov@pnn.lukoil.com). Wanli Kang (Scopus ID 7202402210) - Doctor of Engineering, Professor (e-mail: kangwanli@126.com). Hongbin Yang (Scopus ID 56126113000) - Doctor of Engineering (e-mail: hongbinyang@upc.edu.cn).

Кетова Юлия Анатольевна (Scopus ID 57215592096) - младший научный сотрудник кафедры «Нефтегазовые технологии» (тел.: +007 952322 14 13, e-mail: ketova.pstu@gmail.com).

Галкин Сергей Владиславович (Scopus ID 36711675500) - доктор геолого-минералогических наук, професcop (тел.: +007 342 219 81 18, e-mail: gnfd@pstu.ru). Контактное лицо для переписки.

Вотинов Александр Сергеевич - инженер (тел.: +007 92236608 36, e-mail: aleksandr.votinov@pnn.lukoil.com).

Ванли Канг (Scopus ID 7202402210) - доктор технических наук, професcop (e-mail: kangwanli@126.com).

Хунбинь Янг (Scopus ID 56126113000) - доктор технических наук (e-mail: hongbinyang@upc.edu.cn). 


\section{Introduction}

One of the most common ways to reduce wellbore fluid watercut in oil wells is to influence the formation water intake profile through injection wells by blocking (reducing) water filtration via the most permeable interbeds. This leads to a change in the filtration flows in the oil formation, involves new oil saturated intervals in the filtration and, eventually, enables a prolonged operation of encroached wells.

Presently, the injection of polymers on the basis of polyacrylamide is the most applicable technology for solving the filtration flow redistribution problems in Russia. This technology has many modifications [1]. Alternative solutions aimed at stabilizing the water intake profiles include the use of cross-linked polymer gels, i.e. three-dimensional structures, in which polymer chains are cross-linked by either ionic or covalent polar bonds. The analysis of literature distinguishes two main groups of the cross-linked polymer gels, such as in situ gel systems and preformed gels [2-4].

The main difference between the in situ and preformed gel technologies is the location of shaping the three-dimensional structure, i.e before or after the injection into the formation. The in situ gels undergo a stage of $3 \mathrm{D}$ structure shaping in the formation, whereas the precrosslinked gels form a 3D structure either during synthesis or during a compound makeup immediately prior to the injection into the formation. Fig. 1 shows a classification of polyacrylamide-based compounds used to control the formation water intake profile.

The study analyzes the current experience of using the stabilization technology of the formation water intake profiles based on various modifications of the cross-linked polymer gels, and gives recommendations for application of the most effective methods in

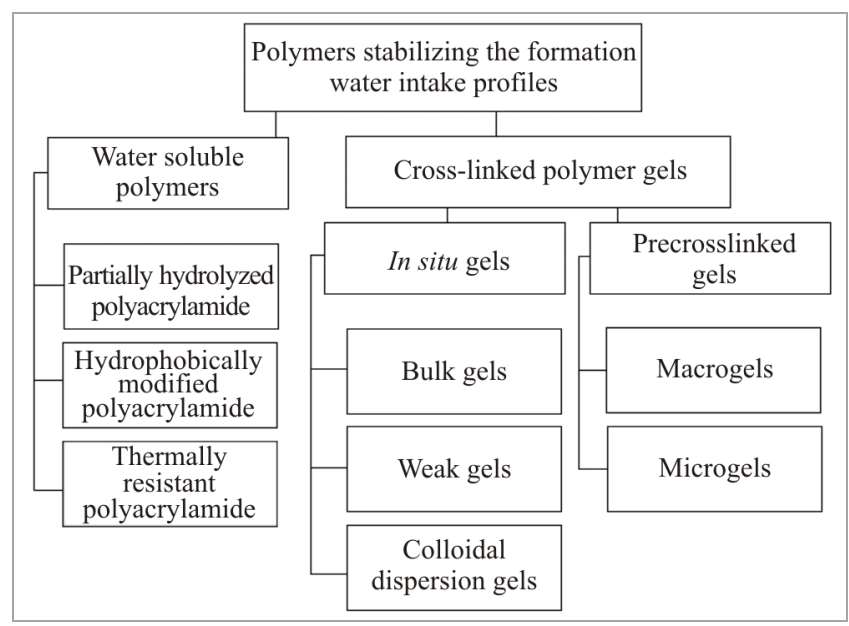

Fig. 1. Classification of polyacrylamide compounds for stabilization of the formation water intake profiles different geological and technological conditions of oilfield operations.

\section{Analysis of Technological Problems of Water Soluble Polyacrylamide Applications in Standard Polymer Water Flooding}

Polymer water flooding has been used in oil production for more than 50 years. Water soluble polyacrylamide increases water viscosity when dissolved in it. The technology is used in oilfields with high viscosity oil (up to $150 \mathrm{mPa} \cdot \mathrm{s}$ ), in the temperature range up to $140{ }^{\circ} \mathrm{C}$, with the formation water salinity up to $270 \mathrm{~g} / \mathrm{L}$. In case the formation oil viscosity is increasing, this technology requires an increased viscosity of the injected polymer solution [5]. The injected viscous polymer solution first fills highly permeable intervals of the formation. This causes an increase in filtration resistance, which, in turn, leads to a further redistribution of the new injected liquid flows to the low-permeability interbeds, and displacement of the residual oil. This process is characterized by mobility ratio, which is a ratio of the water phase mobility to the oil phase mobility [6]:

$$
M_{r}=\frac{k_{w} \cdot \mu_{\mathrm{o}}}{k_{\mathrm{o}} \cdot \mu_{w}}
$$

where $k_{w}$ and $k_{0}$ are the water and oil specific permeability coefficients, $\mu_{o}$ and $\mu_{w}$ are the oil and water viscosities.

An effective oil displacement process requires the mobility ratio to be below one. With the polymer water flooding, this is achieved by increasing the viscosity of the injected water phase. The polymer solution viscosity is selected on the basis of cost effectiveness and possibility to inject the polymer. The effectiveness of the polymer water flooding depends on the dynamics of rheological parameters of the polymer solution in the formation conditions $[7,8]$. The polymer sedimentation in presence of polyvalent metals and polymer adsorption on rock surfaces can significantly reduce the water phase viscosity and, consequently, the water flooding effectiveness. The polymer adsorption process in oilcontaining pores can lead to their blocking [9].

During the injection, the polymer solution viscosity can fall due to the three main reasons, i.e. chemical, mechanical and thermal exposures. Chemical destruction of polymers occurs due to redox reactions between the formation water components and possible radical reactions; mechanical degradation occurs in the pumping equipment and at high injection rates; the viscosity of regular polyacrylamide can also fall due to thermal exposure. In order to minimize the polymer 
destruction processes, polyacrylamide modifications have been developed, which are described in [10].

Partially hydrolyzed polyacrylamide is the most widely spread polymer modification (Fig. 2, a). The polymer increases the solution viscosity at lower concentrations of the polymer compared to regular polyacrylamide, and is more resistant to chemical destruction. The hydrolyzation degree can vary from 25 to $35 \%$, whereas the presence of carboxyl groups in the polymer structure make the chain more rigid owing to their mutual repulsion. Introduction of carboxyl groups into the polymer chain does not fully solve the problem of the rheological properties stability. The presence of metal salts in polyacrylamide solution can make its viscosity significantly lower [11]. In order to ensure thermal stability of polyacrylamide in the conditions of high temperature formations, polyacrylamide chain is modified by adding extra monomers increasing its thermal stability, e.g. 2-acrylamido-2methylpropane sulfonic acid (Fig. 2, b), vinylpyrrolidone etc. Hydrophobically modified polyacrylamide is polyacrylamide chain with integrated hydrophobic monomers (less than $5 \%$ from acrylamide quantity), which can be located at polymer ends or in the chain. In water medium, hydrophobic parts of the polymer gather in groups and form microdomains that stabilize rheological properties of the polymer solution.

Lessons learned from the implementation of the polymer water flooding method suggest that it has certain drawbacks. Polyacrylamide and partially hydrolyzed polyacrylamide are very sensitive to concentrations of metal ions in reservoir water and high formation temperatures (more than $90{ }^{\circ} \mathrm{C}$ ). Dependence of rheological properties of the solutions on water salinity leads to a mismatch between the actual and planned

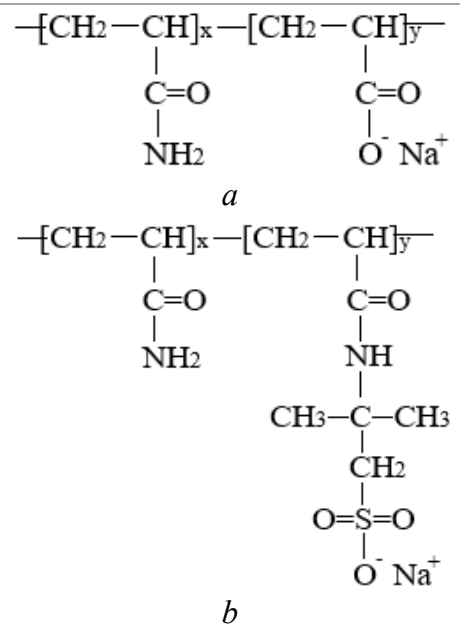

Fig. 2. Structure of modified polyacrylamide: $a$ is partially hydrolyzed; $b$ is sulfonated viscosity value during the technology implementation. Besides, at high injection rates of pumping units, the polymer chains tend to break, which leads to the solution's viscosity decrease. All chemical modifications of polyacrylamide directed at stabilization of rheological properties can only partially rectify the technology drawbacks, but significantly increase its cost. Apart from the cost of the reagents, it is notable that the technology implementation requires expensive stationary equipment for the makeup of the reagent solutions in a nitrogen atmosphere.

The cross-linked polymer gels help to significantly increase the technology effectiveness by stabilizing the rheological properties and reducing the polymer molecules' adsorption on the rock surface. Their analysis is given below.

\section{Analysis of Geological and Technological Conditions for an Effective Use of In Situ Gel Compounds}

In situ polymer gel compounds consist of the two main components, i.e. high-molecular-weight polymer and cross-linking agent, the latter is capable of forming bonds with respective polymer chain fragments. The process of shaping into a 3D structure occurs in the formation after injection. The cross-linking agent is added to the polymer solution in the process of makeup at the wellhead. The solution of the polymer and crosslinking agent is called gelant. Such cross-linking agents can be polyvalent metals or organic compounds. The most common inorganic cross-linking agents are aluminum $\left(\mathrm{Al}^{3+}\right)$ and chromium $\left(\mathrm{Cr}^{3+}\right)$ salts; iron $\left(\mathrm{Fe}^{3+}\right)$ and zirconium $\left(\mathrm{Zr}^{4+}\right)$ ions are also used [12-14]. Salts of the polyvalent metals dissociate in water into ions and enter into the ionic interaction with carboxyl groups of suspensions of precrosslinked gel particles (PGP).

Inorganic cross-links are recommended at the formation temperatures up to $60{ }^{\circ} \mathrm{C}$. This is associated with a high cross-linking speed, which significantly increases the compound viscosity, making the compound difficult to inject into the formation [15]. At the formation temperature above $80{ }^{\circ} \mathrm{C}$, organic crosslinks are used to form heat-resistant bonds between the polymer chains. Covalent bonds are formed between amide groups of the polymer chains and the crosslinking agent. Compared to ionic bonds formed by metal cross-links, the covalent bonds are more resistant to high temperatures [16]. Low compound viscosity during injection and the possibility to control a $3 \mathrm{D}$ structure shaping time are among other advantages of the organic cross-links [17]. The following compounds can be used as cross-linking agents:

- phenol and formaldehyde derivatives (specifically, 2,4,6-hydroxymethylolphenol) [18]. The cross-link is 
used in oilfields with the formation temperatures of $70-80{ }^{\circ} \mathrm{C}$ in alkaline conditions [19]

- resorcin and urotropin for low-temperature formations with a high formation water salinity [20]

- a blend of pyrocatechin, resorcin and pyrogallol, which has been successfully tested at $150^{\circ} \mathrm{C}$ [21]

- polyethyleneimine for cross-linking PAA at $130^{\circ} \mathrm{C}[22]$ etc.

In terms of rheological characteristics, in situ polymer gels exist in several varieties depending on the polymer concentration. In [23] they are distinguished into the following basic types: bulk gels, weak gels, colloidal dispersion gels (CDG). Bulk gels are formed at $4,000 \mathrm{mg} / \mathrm{L}$ concentration of the partially hydrolyzed polymer. At such a high polymer concentration, the cross-linking agents added to the solution can only form intermolecular bonds, connecting polymer chains into a 3D structure. The cross-linked polymer viscosity can exceed $30,000 \mathrm{mPa} \cdot \mathrm{s}$, while the thermal stability of the bulk gel is limited to $120^{\circ} \mathrm{C}$. Weak gels are formed at polymer concentrations of 800 to $2000 \mathrm{mg} / \mathrm{L}$. Their viscosity can vary in the range from 100 to 10,000 $\mathrm{mPa} \cdot \mathrm{s}$, depending on the cross-link type and concentration. Ionic cross-links stabilize the 3D structure up to $80{ }^{\circ} \mathrm{C}$, covalent polar cross-links stabilize the $3 \mathrm{D}$ structure up to $100^{\circ} \mathrm{C}$.

The overview [24] about the successful practices of in situ gel use contains examples of treatments that helped to substantially reduce the wellbore fluid watercut. Generally, in situ gels have high penetration ability. Choosing the right cross-linking agent recipe can increase the 3D structure shaping time to $8 \mathrm{~h}$, making the technology useful for blocking encroached channels in the formation uninvaded zone (FUZ). Nevertheless, the following drawbacks of using in situ gel systems can be mentioned:

- the gel disintegrates at high injection rates and in pumping units

- varying molecular weights of polymer chains of the compound cause non-uniformity of the polymer injection into the formation. Thus, polymer chains with a lower molecular weight can be injected faster and farther (chromatographic effect), they can penetrate low-permeability oil interbeds and block filtration in them

- the gel is sensitive to $\mathrm{pH}$, temperature, and the formation water salinity, making it difficult to control mechanical characteristics of the gel in the formation.

The position of the colloidal dispersion gels in the classification of the cross-linked polymer systems varies in different sources. Some authors classify them as in situ gels [2, 4], others [3] classify them as microgels. This type is a transitory polymer structure between in situ gels and preformed gels. Polymer concentration in CDG is only $100-1200 \mathrm{ppm}$. At such a low content, the polymer chains in presence of a crosslinking agent undergo intramolecular cross-linking, forming globules of a certain shape and size, stable in the range of temperatures from 40 to $94{ }^{\circ} \mathrm{C}$. The polymer concentration in the solution, intended for the colloidal dispersion gel formation, must be below the critical concentration, which is calculated by the formula (2) [25].

$$
C=M /\left[N_{A}\left(2 R_{g}\right)^{3}\right],
$$

where $M$ is the polymer molecular weight; $N_{A}$ is Avogadro number; $R_{g}$ is the radius of gyration.

The polymer chains in presence of the cross-links (polyvalent metals) form 1-150 nm globules [26]. Formation of microspheres can be determined by the solution viscosity decrease [27]. Colloidal disperse gels have proven to be highly effective in oilfields of China, USA, Argentina, and Columbia [28-30]. Study [31] proposes the basic parameters of the colloidal gel injection technology implementation in oilfields. It is recommended to plan CDG operations so as to avoid a jump in the injection pressure and polymer drive-out from the well together with the product. Therefore, the injection pressure should be controlled through particle concentration, polymer to cross-link concentration ratio, and injection rate. The reduction of the filtration flow velocity helps to minimize the reagent's effect on the bottom-hole zone (BHZ) and improve accuracy of the compound injection into the necessary highly permeable interval. Prevention of the reagent drive-out from the formation through the producing well can be achieved through the practice of the preliminary injection of in situ gel into the formation before CDG injection [32]. Formations treatment can be staged, depending on the injection pressure dynamics. At high initial permeability of the formation, more concentrated CDG suspension is used; the increasing injection pressure requires reduction of the gel concentration and particle size without changing the injection pressure [33]. The basic geological and technological conditions of the CDG technology in wells are shown in Table 1.

It is possible to use the colloidal dispersion gels for low permeability formations from $10 \mathrm{mD}$. Compared to the polymer water flooding or treatment with in situ gel, the CDG technology has a number of advantages, such as a selective treatment of a formation (globules cannot penetrate low permeability oil intervals); better effectiveness at low polymer consumptions; higher polymer capability to enter FUZ. Drawbacks of the colloidal dispersion gel technology are the same as in the case of in situ gels: particle structure destruction by mechanical impacts 
(in pumping units and at a high injection rate), and in contact with the formation water ions $[34,35]$.

Table 1

Basic geological and technological conditions of CDG technology

\begin{tabular}{|l|c|}
\hline \multicolumn{1}{|c|}{ Parameter } & Indicator \\
\hline \multicolumn{1}{|c|}{ Formation characteristics } \\
\hline Temperature, ${ }^{\circ} \mathrm{C}$ & $25-100$ \\
\hline Permeability, $\mathrm{mD}$ & $10-4200$ \\
\hline Oil viscosity, cPs & $5-30$ \\
\hline Initial pressure, atm & $0-95$ \\
\hline \multicolumn{2}{|c|}{ Treatment parameters } \\
\hline $\begin{array}{l}\text { Concentration during treatment, } \\
\text { ppm }\end{array}$ & $250-1200$ \\
\hline Cross-link & Aluminum citrate $(23-31)$ \\
\cline { 2 - 2 } & Chromium acetate $(8-31)$ \\
\hline Polymer to cross-link ratio & $20: 1$ to $80: 1$ \\
\hline Injection speed, $\mathrm{m}^{3} / \mathrm{day}$ & $24-320$ \\
\hline Maximum injection pressure, atm & $50-150$ \\
\hline Injection volume, $\mathrm{m}^{3} /$ well & $1600 \ldots>104000$ \\
\hline
\end{tabular}

\section{Analysis of Geological and Technological Conditions for Effective Use of Cross-Linked Polymer Compounds Based on Macrogels}

Precrosslinked polymer gels are polymer particles of a certain size distributed in a dispersion medium, thus forming a suspension. These polymers were designed to rectify drawbacks of in situ technology; specifically, to reduce the polymer destruction under the effect of mechanical and chemical factors. Inherently, polymer particles are absorbents, i.e. they are capable of limited swelling in water and filling the most permeable encroached interbeds. As a result, filtration flows are redistributed to less permeable uninvaded intervals of the section, thus they increase the productivity and depletion period of the producing wells.

The precrosslinked gels can be divided into two main types: macrogels (preformed particle gels (PPG)) and microgels (Bright Water (thermotropic gels)). A choice between the reagent types is based on the technical and geological conditions of specific production sites.

Macrogels are particles obtained using the method of bulk polymerization with further drying and mechanical fragmentation down to the desired fraction size. Particle sizes for compounds classified as macrogels range between $100 \mu \mathrm{m}$ to several $\mathrm{cm}$. Particles of this size in the English-language literature are commonly termed as the preformed particle gel (PPG). PPG particles are characterized with the absorption capacity (a weight of water absorbed by a unit weight of a polymer) in the formation water from 1 to $100 \mathrm{~g} / \mathrm{g}$, the stability in saline water, and the thermal stability at $140^{\circ} \mathrm{C}$ during more than one year. Morphological and absorption characteristics can be controlled by changing a polymer recipe $[36,37]$.

By now, the PPG technology has been used in deposits with high watercut formations for more than 20 years. In the native oilfields, this technology is limited to developing polymer compounds and pilot production operations. So, study [38] contains results of successful filtration tests of the PPG reagent adapted to the conditions of oilfields in the Volga-Ural oil and gas province (formation temperature below $30^{\circ}$ and high salinity of the formation water).

Globally, the PPG technology presently accounts for more than 4000 well operations [39]. Many successful instances are known when the PPG technology was used in high temperature and low temperature formation conditions, with various degrees of salt content in the formation water, in carbonate reservoirs and terrigenous formations. The basic limitation is applicability of the PPG technology only in conditions of reservoirs with permeability above 500 $\mathrm{mD}$. Injection of macrogels into less permeable reservoirs can lead to BHZ blocking and, consequently, well shutting-in. This fact significantly reduces the potential extent of production sites where PPG could be used in the native oilfields. For instance, in Perm Krai only about 60 production sites, which is about $10 \%$ of all wells, have reservoir permeability exceeding 500 $\mathrm{mD}$. Thus, for most oil wells, the PPG technology needs adaptation. For medium permeability reservoirs, the cross-linked polymer gels with higher filtration characteristics are required.

\section{Analysis of Geological and Technological Conditions for Effective Use of Cross-Linked Polymer Compounds Based on Microgels}

The analyzed international experience of using the cross-linked polymer gels to reduce formation watercuts shows that in the conditions of reservoirs with 100 to $500 \mathrm{mD}$ permeability, microgels with a particle size from 0.1 to $30 \mu \mathrm{m}$ have the highest effectiveness (Fig. 3). Fig. 3, $a$, shows a suspension of microgels with a concentration of $100 \mathrm{mg} / \mathrm{L}$, where the size of swollen particles amounts to $25 \mu \mathrm{m}$. Fig. 3, $b$, shows the distribution of swollen microgel particles (size $10-100 \mu \mathrm{m}$ ) in pore channels with throats of $200-1000 \mu \mathrm{m}$. Fig. $3, b$, shows how particles group in the pore space, completely filling it [43].

The cross-linked microgels can be obtained using two basic methods, the method of explosive polymerization and inverse emulsion polymerization. The explosive polymerization method is simple and cost-effective, but difficult in terms of controlling sizes and morphological characteristics of particles. 


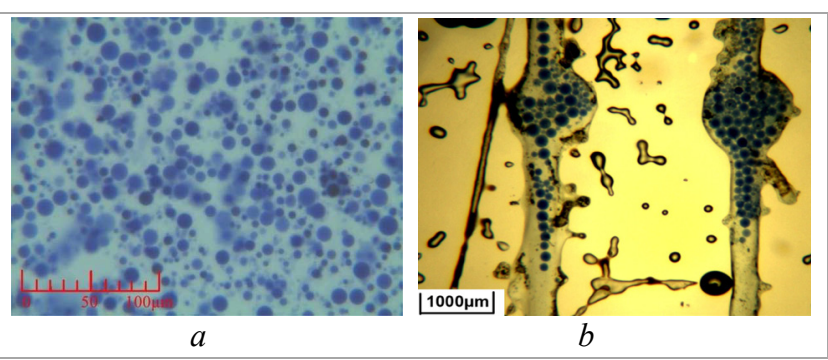

Fig. 3. Distribution of polyacrylamide microgel particles with a concentration of $100 \mathrm{mg} / \mathrm{L}$ [42] (a) and microspheres in the micromodel [43] $(b)$ based on the electronic microscopy data

The inverse emulsion method resolves the aforementioned drawbacks and simplifies the control of a particle size during synthesis [40]. Polymer particles obtained through the inverse emulsion method have a size of 0.1 to $50 \mu \mathrm{m}$ and are capable of swelling fivefold. The maximum absorption capacity is achieved in 10-50 days depending on the particle structure and formation temperature [41-45]. Swelling kinetics and absorption capacity of microspheres also depend on certain formation water salinity. Microgels of this type are widely used in Chinese oilfields (Daqin, Jidong, Dagan, Shengli) [46, 47].

There are several varieties of microgels, e.g. standard cross-linked, temperature sensitive (Brightwater), $\mathrm{pH}$-sensitive. The experience of using standard microgels in Jidong field (the formation temperature is $90{ }^{\circ} \mathrm{C}$, the formation water salinity is $5 \mathrm{~g} / \mathrm{L}$ ) is described in [47]. In the conditions of the pronounced formation inhomogeneity ( $k$ from 10 to $1000 \mathrm{mD}$ ), the water intake profile stabilization was performed using microgels with a mean particle size in the dry state $21 \mu \mathrm{m}$ (scatter 0.4 to $50 \mu \mathrm{m}$ ). The reagent injection was performed in two stages. Initially, to block the largest channels, microspheres with sizes of 20 to $50 \mu \mathrm{m}$ were injected in the concentration of $2000 \mathrm{mg} / \mathrm{L}$; at a later stage, particles with sizes of $0.4-30 \mu \mathrm{m}$ and suspension concentration of $1500 \mu \mathrm{m}$ were injected. The microgel mother solution was supplied through a dosing pump during the injection. During 65 days of wells treatment using this technology, the injection pressure has gradually grown from 10 to $14 \mathrm{MPa}$, which confirms the injection effectiveness. Eventually, the obtained operational benefit was substantial, as the wellbore fluid watercut decreased from 43 to $28 \%$, on average [47].

Bright-water is an instance of the temperature sensitive microgels, the product jointly developed by BP, Chevron, Texaco, and Nalco. Polymer particles of the Bright-water microgel have the size of 0.1-1 $\mu \mathrm{m}$ in a dry condition, and high penetration ability. For this reagent, the formation temperature triggers the process of sharp and irreversible swelling of particles, thereby strongly reduces the reservoir permeability. The microgel particles swelling mechanism is controlled by the proportion of the two types of the polymer cross-links: stable and unstable. The quantity of the stable cross-links in a particle is $200-600$ times more than the quantity of the unstable cross-links, since they ensure polymer stability and prevent its dissolution in the formation water. The size of the swollen particles and swelling speed (type and quantity of cross-links) has to be comparable with the size of reservoir pores. The recommended geological and technological conditions of the technology applications are as follows: highly permeable porous reservoir, minimum fracturing, temperature from 50 to $150^{\circ} \mathrm{C}$, water salinity less than $7 \%$.

Study [48] contains a description of a pilot production operations based on the Bright Water technology at Milne Point field (Alaska) on one injection well and two producing wells. Initially, the injection of particles was performed at a high rate in order to push them through BHZ. After exiting BHZ, the particles filled the most permeable intervals of the formation. Under the effect of the formation temperature $\left(50-75{ }^{\circ} \mathrm{C}\right)$ the temporary cross-link was destroyed and swelling of the particles occurred. The injection well absorbed nearly $270 \mathrm{~m}^{3}$ reagent per day at a pressure of 150 atmospheres during 21 days. Overall, 60.8 tons of the polymer were injected at a concentration of $3300 \mathrm{ppm}(0.33 \%)$ in the water. The resulting oil gain for the first producing well was obtained nine months after the treatment, for the second well it was eleven months after the treatment. The operational profitability effect from the treatment lasted for about two years [48].

Generally, it can be concluded that the use of microgels versus in situ compounds significantly reduces the risks of the polymer chain destruction by mechanical, chemical and thermal factors, which is caused by the $3 \mathrm{D}$ polymer structure. Unlike the PPG technology, the microgels can increase the technology application scope manifold due to their ability to effectively enter the formation at permeability values starting from $100 \mathrm{mD}$.

\section{Conclusion}

The analysis of lessons learned from applying various polymer technologies has shown that a series of promising methods is successfully implemented abroad to reduce watercut of wells at advanced stages of operation. The data were used to develop recommendations concerning the selection of the precrosslinked polymer gel technology taking into account the reservoir permeability (Table. 2). 
Table 2

Use of precrosslinked polymer gels depending on reservoir permeability

\begin{tabular}{|l|c|c|}
\hline \multicolumn{1}{|c|}{ Gel type } & Particle size & $\begin{array}{c}\text { Recommended } \\
\text { reservoir } \\
\text { permeability }\end{array}$ \\
\hline Colloidal dispersion gels & $1-150 \mathrm{~nm}$ & $10-100 \mathrm{mD}$ \\
\hline Microgels & $0.1-50 \mu \mathrm{m}$ & $100-500 \mathrm{mD}$ \\
\hline Macrogels & $50 \mu \mathrm{m}-1 \mathrm{~cm}$ & More than $500 \mathrm{mD}$ \\
\hline
\end{tabular}

The innovative technology, which is recommended in order to reduce the wellbore fluid watercut in reservoirs with permeability more than $500 \mathrm{mD}$ consists in using macrogels. As for reservoirs with permeability from 100 to $500 \mathrm{mD}$, it is advisable to use microgels, while the colloidal dispersion gels are recommended for reservoirs with permeability from 10 to $100 \mathrm{mD}$. To improve the development effectiveness, the advanced technologies need to be adapted to certain geological and technological conditions of pilot production operations in native oilfields.

\section{Acknowledgements}

The work has been supported by the Russian Ministry of Education and Science within the Federal Targeted Programme for Research and Development in Priority Areas of Development of the Russian Scientific and Technological Complex for 2014-2020 (Unique project ID RFMEFI62120X0038), and by Perm Krai Administration within funding under the Grant for Scientific Research of International Research Groups (Project C-26/174.7).

\section{References}

1. Ketova Iu.A., Baodzhan Bai, Kazantsev A.L., Galkin S.V. Analiz effektivnosti primeneniia zavodneniia neftenosnykh plastov na osnove vodorastvorimogo poliakrilamida i predvaritel'no sshitykh poliakrilamidnykh chastits [Analysis of the efficiency of waterflooding of oil reservoirs Using water-soluble polyacrylamide and preliminary crosslinked polyacrylamide particles]. Vestnik Permskogo natsional'nogo issledovatel'skogo politekhnicheskogo universiteta. Geologiia. Neftegazovoe i gornoe delo, 2019, vol. 19, no. 3, pp. 260-270

2. Baojun Bai, Jia Zhou, Mingfei Yin. A comprehensive review of polyacrylamide polymer gels for conformance control. Petroleum exploration and development, 2015, vol. 42, pp. 525-532. DOI: https://doi.org/10.1016/S1876-3804(15)30045-8

3. Abdilbaki Mazen, Huh Chun, Sepehrnoori Kamy, Delshad Mojdeh, Varavei Abdoljalil. A critical review on use of polymer microgels for conformance control purposes. Journal of Petroleum Science and Engineering, 2014, iss. 122, pp. 741-753. DOI: https://doi.org/10.1016/j.petrol.2014.06.034

4. Zhu D., Bai B., Hou J. Polymer Gel Systems for Water Management in HighTemperature Petroleum Reservoirs: A Chemical Review. Energy Fuels, 2017, no. 31, pp. 13063-13087. DOI: https://doi.org/10.1021/acs.energyfuels.7b02897

5. Toma A., Saiuk B., Abirov Zh., Mazbaev E. Polimernoe zavodnenie dlia uvelicheniia nefteotdachi na mestorozhdeniiakh legkoi i tiazheloi nefti [Polymer Flooding to Increase Oil Recovery at Light and Heavy Oil Fields]. Territoriia "NEFTEGAZ", 2017, no. 7-8, pp. 58-67.

6. Kamal M.S., Sultan A.S., Al-Mudaiyedh U.A., Hussein I.A. Review on Polymer Flooding: Rheology, Adsorption, Stability, and Field Applications of Various Polymer Systems. Polymer Reviews, 2015, pp. 1-40. DOI: https://doi.org/10.1080/15583724.2014.982821

7. Silva P.G., Aguiar A.A., Rezende V.P., Monsores A.L.M., Lucas E.F. A polymer flooding mechanism for mature oil fields: laboratory measurements and field results interpretation. $J$. of Petroleum Science and Engineering, 2018, vol. 161, pp. 468-475. DOI: https://doi.org/10.1016/j.petrol.2017.12.008

8. Nazhisu, Erofeev V.I. Issledovanie i primenenie tekhnologii polimernogo zavodneniia dlia povysheniia nefteotdachi plastov [Research and application of polymer flooding technology to enhance oil recovery]. Uspekhi sovremennogo estestvoznaniia, 2018, no. 11, part 2, pp. 420-424. DOI: https://doi.org/10.17513/use.36963

9. Sheng J.J., Leonhardt B., Azri N. Status of Polymer-Flooding Technology. J. of Canadian Petroleum Technology, 2015, vol. 54, iss. 02, pp. 116-126. DOI: https://doi.org/10.2118/174541-PA

10. Wever D.A.Z., Picchinoni F., Broekhuis A.A. Polymers for enhanced oil recovery: A paradigm for structure-property relationship in aqueous solution. Progress in polymer science, 2011, no. 36, pp. 1558-1628. DOI: https://doi.org/10.1016/j.progpolymsci.2011.05.006

11. Seright R.S., Campbell A.R., Mozley P.S., Han P. Stability of Partially Hydrolyzed Polyacrylamides at Elevated Temperatures in the Absence of Divalent Cations. SPE Journal, vol. 15, iss. 02, pp. 341-348. DOI: https://doi.org/10.2118/121460-PA

12. Gussenov I., Nuraje N., Kudaibergenov S. Bulk gels for permeability reduction in fractured and matrix reservoirs. Energy Reports, 2019, no. 5, pp. 733-746. DOI: https://doi.org/10.1016/j.egyr.2019.06.012

13. Jain R., McCool C.S., Green D.W., Willhite G.P., Michnick M.J. Reaction Kenitics of the Uptatke of Chromium (III) Acetate by Polyacrylamide. SRE Journal, 2005, vol. 10, no. 3, pp. 247-254. DOI: https://doi.org/10.2118/89399-PA 
14. Xiangguo L., Junxiang L., Rongian W., Yigang L., Song $\mathrm{Zh}$. Study of action mechanisms and properties of $\mathrm{Cr} 3+$ cross-linked polymer solution with high salinity. Petroleum Science, 2012, no. 9, pp. 75-81. DOI: https://doi.org/10.1007/s12182-012-0185-x

15. Zhu D., Hou J., Meng X., Zheng Z., Qi Wei, Yuguang Chen, Baojun Bai. Effect of Different Phenolic Compounds of Performance of Organically Cross-Linked Terpolymer Gel Systems at Extremely High Temperatures. Energy Fuels, 2017. DOI: https://doi.org/10.1021/acs.energyfuels.7b01386

16. Amir Z., Said I.M., Jan B.M. In situ organically cross-linked polymer gel for high-temperature reservoir conformance control: A review. Polym Adv Technol, 2019, no. 30, pp. 13-39. DOI: https://doi.org/10.1002/pat.4455

17. Bryant S.L., Bartosek M., Lockhart T.P. Laboratory evaluation of phenol-formaldehyde polymer gelants for high-temperature application. Journal of Pertoleum Science and Engineering, 1997, no. 17, pp. 197-209. DOI: https://doi.org/10.1016/S0920-4105(96)00079-4

18. Wang Z., Gao S., You J., Yu J., Jiang T., He D., Gong H., Zhang T., Wei J., Guo S. Synthesis and application of water-soluble phenolformaldehyde resin crosslinking agent. $3^{\text {rd }}$ International Conference on Energy Materials and Environment Engineering. IOP Conf. Series: Earth and Environmental Science, 2017, no. 61. DOI: https://doi.org/10.1088/1755-1315/61/1/012150

19. Albonico P., Bartosek M., Malandrino A., Bryant S., Lockhart T.P. Studies on PhenolFormaldehyde Crosslinked Polymer Gels in Bulk and in Porous Media. SPE International Symposium on Oilfield Chemistry, 14-17 February, San Antonio, Texas, 1995. DOI: https://doi.org/10.2118/28983-MS

20. Sun Y., Fang Y., Chen A., You Q., Dai C., Cheng R., Liu Y. Gelation Behavior Study of a Resorcinol-Hexamethylenetetramine Crosslinked Polymer Gel for Water Shut-Off Treatment in Low Temperatur and High Salinity Reservoirs. Energies, 2017, vol. 10, no. 913. DOI: https://doi.org/10.3390/en10070913

21. Zhu D., Hou J., Meng X., Zhend Z., Wei Q., Chen Y., Bai B. Effect of Different Phenolic Compounds on Performance of Organically Cross-Linked Terpolymer Gel Systems at Extremely High Temperatures. Energy Fuels, 2017. DOI: https://doi.org/10.1021/acs.energyfuels.7b01386

22. Al-Muntasheri G.A., Nasr-El-Din H.A., Zitha P.L.J. Gelation Kinetics and Performance Evaluation of an Organically Crosslinked Del at High Temperature and Pressure. SPE Journal, 2008, vol. 13, iss. 03, pp. 337-345. DOI: https://doi.org/10.2118/104071-PA
23. Zhu D., Bai B., Hou J. Polymer Gel Systems for Water Management in High-Temperature Petroleum Reservoirs: A Chemical Review. Energy Fuels, 2017, no. 31, pp. 13063-13087. DOI: https://doi.org/10.1021/acs.energyfuels.7b02897

24. Amir Z., Said I.M., Jan B.M. In situ organically cross-linked polymer gel for hightemperature reservoir conformance control: a review. Polym Adv Technol, 2018, pp. 1-27. DOI: https://doi.org/10.1002/pat.4455

25. Yung Q., Chu B. Overlap Concentration of Macromolecules in Silution. Macromolecules, 1987, no. 20, pp. 362-366. DOI: https://doi.org/10.1021/ma00168a023

26. Castro-Garcia R.-H., Maya-Toro G.A., Sandoval-Munoz J.E., Cohen-Paternina L.-M. Colloigal Despersion Gels (CDG) to Improve Volumetric Sweep Efficiency in Waterflooding Processes. Latin American journal of Oil \& Gas and Alternative Energies, vol. 5, no. 3, pp. 61-78.

27. Magny Bjorsvik, Harad Hoiland, Arne Skauge Formation of colloidal dispersion gel from aqueous polyacrylamide solution. Colloids and Surfaces A: Physicochem. Eng. Aspects, 2008, no. 317, pp. 504-511. DOI: https://doi.org/10.1016/j.colsurfa.2007.11.025

28. Smith J.E., Liu H., Guo Z.D. Laboratory Studies of In-Depth Colloidal Dispersion Gel Technology for Daqing Oil Field. Presented at the SPE/AAPG Western Regional Meeting, Long Beach, California, USA, 19-22 June. Society of Petroleum Engineers, 2000. DOI: https://doi.org/10.2118/62610-MS

29. Chang H.L., Sui X., Xia L. et al. Successful Filed Pilot of In-Depth Colloidal Dispersion Gel (CDG) Technology in Daqing Oil Field. SPE Reservoir Evaluation \& Engineering, vol. 09, no. 06, pp. 664-673. DOI: https://doi.org/10.2118/89460-PA

30. Diaz D., Saez N., Cabrera M., Manrique E., Romero J., Kazempour M., Aye N. CDG in a Heterogeneous Fluvial Reservoir in Argentina: Pilot and Field Expansion Evaluation. SPE/EOR Kuala Lumpur, Malaysia, 11-13 August 2015. DOI: https://doi.org/10.2118/174704-MS

31. Manrique E., Reyes S., Romero J., Aye N., Kiani M., North W., Tomas C., Kazempour M., Izadi M., Roostapour A., Munix G., Cabrera F., Lantz M., Norman C. Colloidal Dispersion Gels (CDG): Field Projects Review. SPE EOR Conference at Oil and Gas West Asia, 31 March - 2 April. Muscat, Oman, 2014. DOI: https://doi.org/10.2118/169705-MS

32. Muruaga E., Flores M., Norman C., Romero J. Combining Bulk Gels and Colloidal Dispersion Gels for Improved Volumetric Sweep Efficiency in a Mature Waterflood. SPE Symposium on Improved Oil 
Recovery, 20-23 April, Tulsa, Oklahoma, USA, 2008, pp. 1-12. DOI: https://doi.org/10.2118/113334-MS

33. Ricks G.V., Portwood J.T. Injection-side Application of MARCIT Polymer Improves Waterflood Sweep Efficiency, Decreases Water-Oil Ratio, and Enhances Oil Recovery in the McElroy Field, Upton Country, Texas. SPE Permian Basin Oil and Gas Recovery Conference, 21-23 March. Midland, Texas, 2000. DOI: https://doi.org/10.2118/59528-MS

34. Manrique E., Reyes S., Romero J., Aye N., Kiani M., North W., Tomas C., Kazempour M., Izadi M., Roostapour A., Munix G., Cabrera F., Lantz M., Norman C. Colloidal Dispersion Gels (CDG): Field Projects Review. SPE EOR Conference at Oil and Gas West Asia, 31 March - 2 April. Muscat, Oman, 2014. DOI: https://doi.org/10.2118/169705-MS

35. Khamees T., Flori R. Investigating the Propagation of the Colloidal Dispersion Gel (CDG) in Thick Heterogeneous Reservoirs Using Numerical Simulation. American Journal of Science, Engineering and Technology, 2019, vol. 4, no. 1, p. 1-17. DOI: https://doi.org/10.11648/j.ajset.20190401.11

36. Bai B., Liu Yu., Coste J.-P., Li L. Preformed Particle Gel for Conformance Control: Transport Mechanism Through Porous Media. SPE Reservoir Evaluation \& Engineering, 2007, vol. 10, no. 2. DOI: https://doi.org/10.2118/89468-PA

37. Bai B., Li L., Liu Yu., Wang Zh., Liu H. Preformed Particle Gel for Conformnce Control: Factors Affecting its Properties and Applications. SPE/DOE Symposium on Improved Oil Recovery, 17-21 April. Tulsa, Oklahoma, 2004. DOI: https://doi.org/10.2118/89389-MS

38. Ketova Iu.A., Bai B., Khizhniak G.P., Gladkikh E.A., Galkin S.V. Testirovanie tekhnologii predvaritel'no sshitykh chastits polimernogo gelia dlia ogranicheniia vodopritokov na fil'tratsionnykh kernovykh modeliakh [Testing the technology of pre-crosslinked polymer gel particles to limit water inflows on core filtration models]. Zapiski gornogo instituta, 2020, vol. 241, pp. 91-96. DOI: https://doi.org/10.31897/PMI.2020.1.91

39. Bai B., Wei M., Liu Yu. Field and Lab Experience with a Successful Preformed Particle GelConformance Control Technology. SPE Production and Operations Symposium, 23-26 March, Oklahoma City. Oklahoma, USA. Society of Petroleum Engineers, 2013. DOI: https://doi.org/10.2118/164511-MS

40. Yang H., Kang W., Liu S., Bai B., Zhao J., Zhang B. Mechanism and Influensing Factors on the Initial Particle Size and Swelling Capability of Viscoelastic Microspheres. Journal of Dispersion Science and Technology, 2015, vol. 36, no. 11. DOI: https://doi.org/10.1080/01932691.2014.1000463
41. Lei G., Li L., Nasr-El-Din H. New Gel Aggregates to Improve Sweep Efficiency During Waterflooding. SPE Reservoir Evaluation \& Engineering, 2011, vol. 14, no. 01, pp. 120-128. DOI: https://doi.org/10.2118/129960-PA

42. Wang B., Lin M., Guo J., Wang D., Xu F., Li M. Plugging properties and profile control effects of crosslinked polyacrylamide microspheres. J. of Applied Polymer Science, 2016, vol. 133, pp. 1-7. DOI: https://doi.org/10.1002/APP.43666

43. Lin M., Zhang G., Hua Z., Zhao Q., Sun F. Conformation and plugging properties of crosslinked polymer microspheres for profile control. Colloids and Surfaces A: Physicochem. Eng. Aspects, 2015, no. 477, pp. 49-54. DOI: http://dx.doi.org/10.1016/j.colsurfa.2015.03.042

44. Yao C., Lei G., Gao X., Li L. Controllable Preparation, Rheology, and Plugging Property of Micron-Grade Polyacrylamide Microspheres as a Novel Profile Control and Flooding Agent. $J$ of Applied Polymer Science, 2013, pp. 1124-1130. DOI: https://doi.org/10.1002/app.39283

45. Dupuis G., Lesuffleur T., Desbois M., Bouillot J., Zaitoun A. Water Conformance Treatment using SMG Microgels: A Successful Field Case. SPE EOR Conference at Oil and Gas West Asia, 21-23 March. Muscat, Oman, 2016. DOI: https://doi.org/10.2118/179765-MS

46. Zhu D., Bai B., Hou J. Polymer Gel Systems for Water Management in High-Temperature Petroleum Reservoirs: A Chemical Review. Energy Fuels, 2017, no. 31, pp. 13063-13087. DOI: https://doi.org/10.1021/acs.energyfuels. 7 b02897

47. Yao C., Lei G., Li L., Gao X. Selectivity of Pore-Scale Elastic Microspheres as a Novel Profile Control and Oil Displacement Agent. Energy Fuels, 2012, no. 26, pp. 5092-5101. DOI: http://dx.doi.org/10.1021/ef300689c

48. Ohms D., McLeod J., Graff C.J., Frampton H., Morgan J.C. Cheung, S., Chang K.I. Incremental-Oil Success From Waterflood Sweep Improvement in Alaska. SPE Production \& Operations, 2010, vol. 25, iss. 03. DOI: https://doi.org/10.2118/121761-PA

\section{Библиографический список}

1. Анализ эффективности применения заводнения нефтеносных пластов на основе водорастворимого полиакриламида и предварительно сшитых полиакриламидных частиц / Ю.А. Кетова, Бай Баоджан, А.Л. Казанцев, С.В. Галкин // Вестник Пермского национального исследовательского политехнического университета. Геология. Нефтегазовое и горное дело. - 2019. - Т. 19, № 3. C. $260-270$. 
2. Baojun Bai, Jia Zhou, Mingfei Yin A comprehensive review of polyacrylamide polymer gels for conformance control // Petroleum exploration and development. - 2015. - Vol. 42. - P. 525-532. DOI: https://doi.org/10.1016/S1876-3804(15)30045-8

3. A critical review on use of polymer microgels for conformance control purposes / Mazen Abdilbaki, Chun Huh, Kamy Sepehrnoori, Mojdeh Delshad, Abdoljalil Varavei // Journal of Petroleum Science and Engineering. - 2014. - Is. 122. - P. 741-753. DOI: https://doi.org/10.1016/j.petrol.2014.06.034

4. Zhu D., Bai B., Hou J. Polymer gel systems for water management in high-temperature petroleum reservoirs: a chemical review // Energy Fuels. - 2017. - № 31. - P. 13063-13087. DOI: https://doi.org/10.1021/acs.energyfuels.7b02897

5. Полимерное заводнение для увеличения нефтеотдачи на месторождениях легкой и тяжелой нефти / А. Тома, Б. Саюк, Ж. Абиров, Е. Мазбаев // Территория «НЕФТЕГАЗ». - 2017. - № 7-8. C. $58-67$.

6. Review on polymer flooding: rheology, adsorption, stability, and field applications of various polymer systems / M.S. Kamal, A.S. Sultan, U.A. Al-Mudaiyedh, I.A. Hussein // Polymer Reviews. - 2015. - P. 1-40. DOI: https://doi.org/10.1080/15583724.2014.982821

7. A polymer flooding mechanism for mature oil fields: laboratory measurements and field results interpretation / P.G. Silva, A.A. Aguiar, V.P. Rezende, A.L.M. Monsores, E.F. Lucas // J. of Petroleum Science and Engineering. - 2018. - Vol. 161. - P. 468-475. DOI: https://doi.org/10.1016/j.petrol.2017.12.008

8. Нажису, Ерофеев В.И. Исследование и применение технологии полимерного заводнения для повышения нефтеотдачи пластов // Успехи современного естествознания. - 2018. - № 11, ч. 2. C. 420-424. DOI: https://doi.org/10.17513/use.36963

9. Sheng J.J., Leonhardt B., Azri N. Status of Polymer-Flooding Technology // J. of Canadian Petroleum Technology. - 2015. - Vol. 54, iss. 02. P. 116-126. DOI: https://doi.org/10.2118/174541-PA

10. Wever D.A.Z., Picchinoni F., Broekhuis A.A. Polymers for enhanced oil recovery: A paradigm for structure-property relationship in aqueous solution // Progress in polymer science. - 2011. - № 36. - P. 1558-1628. DOI: https://doi.org/10.1016/j.progpolymsci.2011.05.006

11. Stability of partially hydrolyzed polyacrylamides at elevated temperatures in the absence of divalent cations / R.S. Seright, A.R. Campbell, P.S. Mozley, P. Han // SPE Journal. - Vol. 15, iss. 02. - P. 341-348. DOI: https://doi.org/10.2118/121460-PA

12. Gussenov I., Nuraje N., Kudaibergenov S. Bulk gels for permeability reduction in fractured and matrix reservoirs // Energy Reports. - 2019. - № 5. - P. 733746. DOI: https://doi.org/10.1016/j.egyr.2019.06.012

13. Reaction kenitics of the uptatke of chromium (III) acetate by polyacrylamide / R. Jain, C.S. McCool, D.W. Green, G.P. Willhite, M.J. Michnick // SRE Journal. - 2005. - Vol. 10, № 3. - P. 247-254. DOI: https://doi.org/10.2118/89399-PA

14. Study of action mechanisms and properties of $\mathrm{Cr} 3+$ cross-linked polymer solution with high salinity / L. Xiangguo, L. Junxiang, W. Rongian, L. Yigang, Zh. Song // Petroleum Science. - 2012. - № 9. - P. 75-81. DOI: https://doi.org/10.1007/s12182-012-0185-X

15. Effect of different phenolic compounds of performance of organically cross-linked terpolymer gel systems at extremely high temperatures // D. Zhu, J. Hou, X. Meng, Z. Zheng, Wei Qi, Chen Yuguang, Bai Baojun // Energy Fuels. - 2017. DOI: https://doi.org/10.1021/acs.energyfuels.7b01386

16. Amir Z., Said I.M., Jan B.M. In situ organically cross-linked polymer gel for hightemperature reservoir conformance control: A review. - Polym Adv Technol. - 2019. - № 30. P. 13-39. DOI: https://doi.org/10.1002/pat.4455

17. Bryant S.L., Bartosek M., Lockhart T.P. Laboratory evaluation of phenol-formaldehyde polymer gelants for high-temperature application // Journal of Pertoleum Science and Engineering. - 1997. - № 17. - P. 197-209. DOI: https://doi.org/10.1016/S0920-4105(96)00079-4

18. Synthesis and application of water-soluble phenol-formaldehyde resin crosslinking agent. $3^{\text {rd }}$ International Conference on Energy Materials and Environment Engineering / Z. Wang, S. Gao, J. You, J. Yu, T. Jiang, D. He, H.Gong, T. Zhang, J. Wei, S. Guo // IOP Conf. Series: Earth and Environmental Science. - 2017. - № 61 . DOI: https://doi.org/10.1088/1755-1315/61/1/012150

19. Studies on phenol-formaldehyde crosslinked polymer gels in bulk and in porous media / P. Albonico, M. Bartosek, A. Malandrino, S. Bryant, T.P. Lockhart // SPE International symposium on oilfield chemistry, 14-17 February, San Antonio, Texas, 1995. DOI: https://doi.org/10.2118/28983-MS

20. Gelation behavior study of a resorcinol-hexamethylenetetramine crosslinked polymer gel for water shut-off treatment in low temperatur and high salinity reservoirs / Y. Sun, Y. Fang, A. Chen, Q. You, C. Dai, R. Cheng, Y. Liu // Energies. - 2017. - Vol. 10, № 913. DOI: https://doi.org/10.3390/en10070913

21. Effect of different phenolic compounds on performance of organically cross-linked terpolymer gel systems at extremely high temperatures / D. Zhu, J. Hou, X. Meng, Z. Zhend, 
Q. Wei, Y. Chen, B. Bai // Energy Fuels. - 2017. DOI: https://doi.org/10.1021/acs.energyfuels.7b01386

22. Al-Muntasheri G.A., Nasr-El-Din H.A., Zitha P.L.J. Gelation kinetics and performance evaluation of an organically crosslinked del at high temperature and pressure // SPE Journal. - 2008. - Vol. 13, iss. 03. - P. 337-345. DOI: https://doi.org/10.2118/104071-PA

23. Zhu D., Bai B., Hou J. Polymer gel systems for water management in high-temperature petroleum reservoirs: a chemical review // Energy Fuels. - 2017. - № 31. - P. 13063-13087. DOI: https://doi.org/10.1021/acs.energyfuels.7b02897

24. Amir Z., Said I.M., Jan B.M. In situ organically cross-linked polymer gel for hightemperature reservoir conformance control: a review // Polym Adv Technol. 2018. - P. 1-27. DOI: https://doi.org/10.1002/pat.4455

25. Yung Q., Chu B. Overlap Concentration of Macromolecules in Silution. // Macromolecules. - 1987. - № 20. - P. 362-366. DOI: https://doi.org/10.1021/ma00168a023

26. Colloigal Despersion Gels (CDG) to Improve Volumetric Sweep Efficiency in Waterflooding Processes / R.-H. Castro-Garcia, G.A. Maya-Toro, J.E. Sandoval-Munoz, L.-M. Cohen-Paternina // Latin American journal of Oil \& Gas and Alternative Energies. - Vol. 5, № 3. - P. 61-78.

27. Magny Bjorsvik, Harad Hoiland, Arne Skauge. Formation of colloidal dispersion gel from aqueous polyacrylamide solution // Colloids and Surfaces A: Physicochem. Eng. Aspects. - 2008. - № 317. - P. 504-511. DOI: https://doi.org/10.1016/j.colsurfa.2007.11.025

28. Smith J.E., Liu H., Guo Z.D. Laboratory studies of in-depth colloidal dispersion gel technology for daqing oil field. Presented at the SPE/AAPG Western Regional Meeting, Long Beach, California, USA, 19-22 June // Society of Petroleum Engineers. - 2000. DOI: https://doi.org/10.2118/62610-MS

29. Successful filed pilot of in-depth colloidal dispersion gel (CDG) technology in daqing oil field / H.L. Chang, X. Sui, L. Xia [et al.] // SPE Reservoir Evaluation \& Engineering. - Vol. 09, № 06. - P. 664-673. DOI: https://doi.org/10.2118/89460-PA

30. CDG in a heterogeneous fluvial reservoir in argentina: pilot and field expansion evaluation / D. Diaz, N. Saez, M. Cabrera, E. Manrique, J. Romero, M. Kazempour, N. Aye // SPE/EOR Kuala Lumpur, Malaysia, 11-13 August. - 2015. DOI: https://doi.org/10.2118/174704-MS

31. Colloidal dispersion gels (CDG): field projects review / E. Manrique, S. Reyes, J. Romero, N. Aye, M. Kiani, W. North, C. Tomas, M. Kazempour, M. Izadi, A. Roostapour, G. Munix, F. Cabrera, M. Lantz, C. Norman // SPE EOR Conference at oil and gas West Asia, 31 March - 2 April. - Muscat, Oman, 2014. DOI: https://doi.org/10.2118/169705-MS

32. Combining bulk gels and colloidal dispersion gels for improved volumetric sweep efficiency in a mature waterflood / E. Muruaga, M. Flores, C. Norman, J. Romero // SPE Symposium on improved oil recovery, 20-23 April. Tulsa, Oklahoma, USA, 2008. P. 1-12. DOI: https://doi.org/10.2118/113334-MS

33. Ricks G.V., Portwood J.T. Injection-side application of MARCIT polymer improves waterflood sweep efficiency, decreases water-oil ratio, and enhances oil recovery in the McElroy field, Upton country, Texas // SPE Permian basin oil and gas recovery conference, 21-23 March. - Midland, Texas, 2000. DOI: https://doi.org/10.2118/59528-MS

34. Colloidal dispersion gels (CDG): field projects review / E. Manrique, S. Reyes, J. Romero, N. Aye, M. Kiani, W. North, C. Tomas, M. Kazempour, M. Izadi, A. Roostapour, G. Munix, F. Cabrera, M. Lantz, C. Norman // SPE EOR conference at oil and gas West Asia, 31 March - 2 April. - Muscat, Oman, 2014. DOI: https://doi.org/10.2118/169705-MS

35. Khamees T., Flori R. Investigating the propagation of the colloidal dispersion gel (CDG) in thick heterogeneous reservoirs using numerical simulation // American journal of science, engineering and technology. - 2019. - Vol. 4, № 1. - P. 1-17. DOI: https://doi.org/10.11648/j.ajset.20190401.11

36. Preformed particle gel for conformance control: transport mechanism through porous media/ B. Bai, Yu. Liu, J.-P. Coste, L. Li // SPE Reservoir Evaluation \& Engineering. - 2007. - Vol. 10, № 2. DOI: https://doi.org/10.2118/89468-PA

37. Preformed particle gel for conformance control: factors affecting its properties and applications / B. Bai, L. Li, Yu. Liu, Zh. Wang, H. Liu // SPE/DOE Symposium on improved oil recovery, 17-21 April. - Tulsa, Oklahoma, 2004. DOI: https://doi.org/10.2118/89389-MS

38. Тестирование технологии предварительно сшитых частиц полимерного геля для ограничения водопритоков на фильтрационных керновых моделях / Ю.А. Кетова, Б. Бай, Г.П. Хижняк, Е.А. Гладких, С.В. Галкин // Записки горного института. - 2020. - Т. 241. - С. 91-96. DOI: https://doi.org/10.31897/PMI.2020.1.91

39. Bai B., Wei M., Liu Yu. Field and lab experience with a successful preformed particle gelconformance control technology // SPE Production and Operations Symposium, 23-26 March, Oklahoma City. - Oklahoma, USA. - Society of Petroleum Engineers, 2013. DOI: https://doi.org/10.2118/164511-MS

40. Mechanism and influensing factors on the initial particle size and swelling capability of 
viscoelastic microspheres / H. Yang, W. Kang, S. Liu, B. Bai, J. Zhao, B. Zhang // Journal of Dispersion Science and Technology. - 2015. - Vol. 36, № 11. DOI: https://doi.org/10.1080/01932691.2014.1000463

41. Lei G., Li L., Nasr-El-Din H. New gel aggregates to improve sweep efficiency during waterflooding // SPE Reservoir Evaluation \& Engineering. - 2011. - Vol. 14, № 01. - P. 120-128. DOI: https://doi.org/10.2118/129960-PA

42. Plugging properties and profile control effects of crosslinked polyacrylamide microspheres / B. Wang, M. Lin, J. Guo, D. Wang, F. Xu, M. Li // J. of Applied Polymer Science. - 2016. - Vol. 133. - P. 1-7. DOI: https://doi.org/10.1002/APP.43666

43. Conformation and plugging properties of crosslinked polymer microspheres for profile control / M. Lin, G. Zhang, Z. Hua, Q. Zhao, F. Sun // Colloids and Surfaces A: Physicochem. Eng. Aspects. - 2015. - № 477. - P. 49-54. DOI: http://dx.doi.org/10.1016/j.colsurfa.2015.03.042

44. Yao C., Lei G., Gao X., Li L. Controllable preparation, rheology, and plugging property of micron-grade polyacrylamide microspheres as a novel profile control and flooding agent //
J. of Applied Polymer Science. - 2013. - P. 1124-1130. DOI: https://doi.org/10.1002/app.39283

45. Water Conformance Treatment using SMG Microgels: A Successful Field Case / G. Dupuis, T. Lesuffleur, M. Desbois, J. Bouillot, A. Zaitoun // SPE EOR Conference at Oil and Gas West Asia, 21-23 March. - Muscat, Oman, 2016. DOI: https://doi.org/10.2118/179765-MS

46. Zhu D., Bai B., Hou J. Polymer gel systems for water management in high-temperature petroleum reservoirs: a chemical review // Energy Fuels. - 2017. - № 31. - P. 13063-13087. DOI: https://doi.org/10.1021/acs.energyfuels.7b02897

47. Selectivity of pore-scale elastic microspheres as a novel profile control and oil displacement agent / C. Yao, G. Lei, L. Li, X. Gao // Energy Fuels. - 2012. - № 26. - P. 5092-5101. DOI: http://dx.doi.org/10.1021/ef300689c

48. Incremental-oil success from waterflood sweep improvement in Alaska / D. Ohms, J. McLeod, C.J. Graff, H. Frampton, J.C. Morgan, S. Cheung, K.I. Chang // SPE Production \& Operations. - 2010. - Vol. 25, iss. 03. DOI: https://doi.org/10.2118/121761-PA

Please cite this article in English as:

Ketova Iu.A., Galkin S.V., Votinov A.S., Kang W., Yang H. Analysis of the international practice in application of conformance control technologies based on cross-linked polymer gels. Perm Journal of Petroleum and Mining Engineering, 2020, vol.20, no.2, pp.150-161. DOI: 10.15593/2224-9923/2020.2.5

Просьба ссылаться на эту статью в русскоязычных источниках следующим образом:

Анализ мирового опыта применения технологий выравнивания профилей приемистости на основе сшитых полимерных гелей / Ю.А. Кетова, С.В. Галкин, А.С. Вотинов, В. Канг, Х. Янг // Вестник Пермского национального исследовательского политехнического университета. Геология. Нефтегазовое и горное дело. - 2020. - Т.20, №2. - С.150-161. DOI: $10.15593 / 2224-9923 / 2020.2 .5$ 